\title{
Evaluation of Metabolic Syndrome as A Risk Factor for Colorectal Cancer
}

\author{
A. Bahnasy ${ }^{1}$, Rawhia Hassan El-Edel ${ }^{2}$, Hanaa El sayed Ahmed Barakat ${ }^{3}$, \\ Abd El Naser Abd El Atty Gadallah ${ }^{1}$
}

'Department of Internal Medicine, Faculty of Medicine, Menoufia University, Egypt 2Department of Pathology, Faculty of Medicine, Menoufia University, Egypt

${ }^{3}$ Department of Internal Medicine, Faculty of Medicine, Kafr El sheikh University, Egypt

\author{
*Corresponding author: \\ Hanaa El sayed Ahmed Barakat M.B.B. Ch \\ Department of Internal Medicine \\ Faculty of Medicine \\ Kafr El sheikh University, Egypt \\ E-mail: smartcenterprivate2020@gmail.com
}

\section{ABSTRACT}

Objective: This study was designed to determine the relationship between metabolic syndrome as a risk factor for colorectal cancer.

Background: Overweight and obesity are leading risks for global deaths. Although the increase in obesity over the last 35 years has been most dramatic in the US and western industrialized countries, similar trends have also been seen in urban areas of many developing countries. There are multiple common health consequences of an elevated body mass index, including risk for several metabolic disorders, some cancers and ultimately increased mortality

Patients and methods: A case control study was carried out on 150 patients 100 cases with colorectal cancer (CRC), and 50 healthy age and sex matched controls. The patients were randomly selected from those attending Gastroenterology Unit in Menoufia University Hospital and Kafr el sheikh University Hospital, Egypt during April 2019 till February 2020. All subjects included in this study divided into Group I included100 patients with (CRC) with colorectal cancer diagnosed based on pathological results and Group II included 50 normal healthy subjects of matched age and sex served.

Results: There was no statistically significant differences between the studied groups regarding gender $(p=0.074)$, and age/year $(p=0.162)$. While, Insulin-like growth factor-1 level and carcinoembryonic antigen were significantly higher among colorectal cancer patients than control groups $(p<0.05)$.

Conclusion: Metabolic syndrome (MetS) is a state of chronic low-grade inflammation as a consequence of complex interplay between genetic and environmental factors.

Key words: metabolic, colorectal, insulin, cancer

\section{INTRODUCTION}

Overweight and obesity are leading risks for global deaths (1). The World Health Organization estimates that at least 2.8 million adults die each year as a result of being overweight or obese (1). Although the increase in obesity over the last 35 years has been most dramatic in the US and western industrialized countries, similar trends have also been seen in urban areas of
Received: 10.09 .2021

Accepted: 24.11.2021

Copyright $\odot$ Celsius Publishing House www.sgo-iasgo.com 
many developing countries. There are multiple Common health consequences of an elevated body mass index (BMI), including risk for several metabolic disorders, some cancers and ultimately increased mortality (2). Cancer is the leading cause of death in developed countries and a second leading cause of death in developing countries. About 12.7 million cancer cases and 7.6 million cancer deaths are estimated to have occurred in 2008. It is estimated that 1,660,290 men and women (854,790 men and 805,500 women) will be diagnosed with and 580,350 men and women will die of cancer of all sites in 2013. The number of cancer cases is expected to rise due to both worldwide population growth and an increasingly aged population (3). Positive association between obesity and CRC prevalence demonstrates an underlying dose-response relationship according to BMI (4). Timely screening of obese patients for CRC is thus recommended. Gastrointestinal malignant tumors involve a variety of diseases, and any of which have poor prognosis. Although only colorectal and pancreatic cancers are among the 10 cancers with the highest incidence rates in the USA, five types of gastrointestinal tumor, including colorectal, pancreatic, hepatic, esophageal, and gastric, are among the 10 cancers with the highest mortality. In Japan, among the 10 cancers with the highest mortality in 2016, six are gastrointestinal tumors, including colorectal, gastric, pancreatic, hepatic, biliary tract, and esophageal. At the time of diagnosis, many patients have either metastatic or unrespectable cancers. Even after curative-intent surgical treatment, the survival time is still limited, and therapies for unresectable carcinomas are typically minimally effective. Therefore, we must seek a new marker to identify gastrointestinal cancers (5).

Signals from a variety of growth factors are required for carcinogenesis and cancer development in humans. The insulin-like growth factor (IGF) system, which includes both ligands of IGF1 and IGF2 and type 1 insulin-like growth factor receptor (IGF1R), may be an important molecular target for cancer therapy (6). Binding of the ligands to IGF1R causes receptor auto phosphorylation and activates multiple signaling pathways, which can stimulate cancer progression and cellular differentiation (7). IGFs are produced by hepatocytes and also by many extrahepatic sites including stromal components and cancer cells. The IGF axis is controlled by multiple steps under homeostatic conditions (8).

\section{PATIENTS AND METHODS}

A case control study was carried out on 150 patients 100 cases with colorectal cancer (CRC), and 50 healthy age and sex matched controls. The patients were randomly selected from those attending Gastroenterology Unit in Menoufia University Hospital and Kafr el sheikh University Hospital, Egypt during the period from April 2019 to February 2020. All subjects included in this study were divided into two groups: Group I: included 100 patients with (CRC) with colorectal cancer diagnosed according to pathological results. Group II: included 50 normal healthy subjects of matched age and sex served.

Inclusion criteria included patients with colorectal cancer (CRC) diagnosed according to pathological results, Patients who did not receive radiotherapy, chemotherapy or other treatment for cancer before operation and All CRC presented as adenocarcinomas. Also, oral drugs for hyper triglyceridemia, hypertension and hyper-glycaemia were not used before and during operation.

Exclusion criteria included patients with acute inflammation, chronic liver and kidney damage, acromegaly, hyperthyroidism, polycystic ovary syndrome, cushing syndrome and other endocrine patients taking glucocorticoids, thyroid hormones, and other endocrine diseases, non-steroidal antiinflammatory drugs, diuretics and other drugs that affect blood sugar and insulin, familial adenomatous polyposis and patients had a history of familial malignancy or other synchronous malignancy (such as ovarian cancer, prostate cancer, breast cancer), were excluded.

All selected patients included in this study were subjected to the following: Full history taking including: A purposely designed sheet was performed for all patients included in this study, including: Personal history: name, age, sex, address, residence, occupation, marital status and special habits (smoking, alcohol), Past history: Any medical disease and its nature, duration, treatment and any drug intake and its regimen and duration of intake and Family history: of any similar condition. Examination: Complete general and local examination. Laboratory examination: Complete blood picture, Kidney functions, Liver function test, Quantification of serum lipid, Insulin like growth factor 1 (IGF-1) and carcinoembryonic antigen (CEA). Radiological investigations, CT and Colonoscopy. 


\section{Statistical analysis}

Results were collected, tabulated, statistically analyzed by IBM personal computer and statistical package SPSS version 22 (Armonk, NY: IBM Corp, 2013). Descriptive statistics included Percentage (\%), mean (x) and standard deviation (SD) and analytic statistics included chi-square test $\left(\chi^{2}\right)$ Student's t-test, Intergroup comparison, Fisher's exact test, Correlation coefficient test (Person test) and ROC curve analysis. $P$ value $<0.05$ was considered statistically significant.

\section{RESULTS}

There were no statistically significant differences between the studied groups regarding gender $(p=0.074)$, age $(p=0.162)$, height $(p=0.670)$, and weight $(p=0.102)$. While, body mass index and waist were significantly lower among colorectal cancer patients than control groups $(p<0.001$ and $p=0.004$, respectively) as shown in table 1.
Carcinoembryonic antigen (CEA) was significantly increased among colorectal cancer patients than control groups. Most of rectal cancer patients had T3NO (32\%) followed by T3N1 and T3N2 (16\% and 16\%). Also, most of colon cancer patients had T3NO and T3N1(29.33\% and 29.33\%) followed by T2N1(11.67\%). While Insulin-Like Growth Factor-1 were significantly higher among colorectal cancer patients than control groups $(\mathrm{p}<0.001)$ as shown in table 2.

There was no statistically significant relation between body mass index and diastolic pressure, systolic pressure, high density lipids, cholesterol, and carcinoembryonic antigen among colon cancer patients. While, triglyceride level was significantly increased among overweight and obese patients than normal patients. Also, waist, and low-density lipid were significantly higher among obese patients than normal and overweight patients $(p=0.001)$. Also, triglycerides were significantly decreased among overweight patients lower than obese and normal patients. Regarding insulin-like growth factor-1 was significantly

Table 1 - Comparison between the studied groups regarding demographic data and anthropometric measurements

\begin{tabular}{|c|c|c|c|c|c|c|}
\hline & \multicolumn{3}{|c|}{ Colorectal cancer patients $(\mathrm{N}=100)$} & Control $(\mathrm{N}=50)$ & \multirow[t]{3}{*}{$\chi^{2}$} & \multirow[t]{2}{*}{ P- Value } \\
\hline & \multicolumn{2}{|c|}{ Rectal (N=25) } & Colon (N=75) & & & \\
\hline & No. & $\%$ & No. & No. & & \\
\hline \multicolumn{7}{|l|}{ Gender } \\
\hline Male & 11 & 44.00 & 54.67 & 34.00 & 2.207 & $0.074^{\mathrm{NS}}$ \\
\hline Female & 14 & 56.00 & 45.33 & 66.00 & & \\
\hline \multicolumn{7}{|l|}{ Age/year } \\
\hline Mean \pm SD & \multicolumn{2}{|c|}{$40.56 \pm 8.66$} & $41.20 \pm 12.40$ & $43.68 \pm 10.14$ & $\mathrm{H}=0.53$ & $0.162^{\mathrm{NS}}$ \\
\hline Range & \multicolumn{2}{|c|}{$25-64$} & $23-67$ & $25-68$ & & \\
\hline Median & \multicolumn{2}{|c|}{39.81} & 40.67 & 42.50 & & \\
\hline \multicolumn{7}{|l|}{ Hight/cm } \\
\hline Mean $\pm S D$ & \multicolumn{2}{|c|}{$165.90 \pm 16.11$} & $172.80 \pm 20.23$ & $168.60 \pm 3.30$ & $F=1.88$ & $0.670^{\mathrm{NS}}$ \\
\hline Range & \multicolumn{2}{|c|}{$160-175$} & $166-180$ & $159-180$ & & \\
\hline Median & \multicolumn{2}{|c|}{155} & 162 & 169 & & \\
\hline \multicolumn{7}{|l|}{ Weight/kg } \\
\hline Mean $\pm S D$ & \multicolumn{2}{|c|}{$87.00 \pm 10.04$} & $90.12 \pm 19.46$ & $90.46 \pm 15.98$ & $\mathrm{H}=0.15$ & $0.102^{\text {NS }}$ \\
\hline Range & \multicolumn{2}{|c|}{$62-124$} & 60-125 & $57-126$ & & \\
\hline Median & & & 88.31 & 91 & & \\
\hline $\mathrm{BMI}\left(\mathrm{kg} / \mathrm{m}^{2}\right)$ & & & & & & \\
\hline Mean \pm SD & & & $25.83 \pm 3.14$ & $29.64 \pm 2.59$ & $H=32.22$ & $<0.001^{* *}$ \\
\hline Range & & & 18.5-35 & 24-35 & & \\
\hline Median & & & 91 & 30 & & \\
\hline Post Hoc & & & $\mathrm{P} 1=0.706, \mathrm{P} 2:<0.0$ & $<0.001^{* *}$ & & \\
\hline Waist circumf & $/ \mathrm{cm}$ & & & & & \\
\hline Mean \pm SD & & & $58.31 \pm 5.68$ & $87.06 \pm 7.93$ & $F=5.783$ & $0.004^{*}$ \\
\hline Range & & & $70-103$ & $70-110$ & & \\
\hline Median & & & 59 & 85 & & \\
\hline Post Hoc & & & $\mathrm{P} 1=0.022^{*}, \mathrm{P} 2=$ & $3=0.132$ & & \\
\hline
\end{tabular}

BMI: Body mass index $\chi^{2}$ : chi square, $\mathrm{H}$ : Kruskal Wallis test, NS: Non statistically significant, F-test: ANOVA F test, *: statistically significant,

**: Highly statistically significant.

$\mathrm{P} 1$ : comparison between Rectal group and Colon group

P2: comparison between Rectal group and Control group

P3: comparison between colon group and Control group 
Table 2 - Comparison between the studied groups regarding pathology and Insulin-Like Growth Factor-1 and CEA

\begin{tabular}{|c|c|c|c|c|c|c|c|}
\hline & \multicolumn{4}{|c|}{ Colorectal cancer patients $(\mathrm{N}=100)$} & \multirow[t]{2}{*}{ Control $(\mathrm{N}=50)$} & \multirow[t]{2}{*}{ F test } & \multirow[t]{2}{*}{$P$ value } \\
\hline & \multicolumn{2}{|c|}{ Rectal (N=25) } & \multicolumn{2}{|c|}{ Colon (N=75) } & & & \\
\hline \multicolumn{8}{|l|}{ IGF1 } \\
\hline Mean \pm SD & \multirow{2}{*}{\multicolumn{2}{|c|}{$\begin{array}{c}86.93 \pm 43.77 \\
6-181\end{array}$}} & \multirow{2}{*}{\multicolumn{2}{|c|}{$\begin{array}{c}66.17 \pm 39.04 \\
17-282\end{array}$}} & $25.14 \pm 11.82$ & \multirow[t]{3}{*}{35.184} & \multirow[t]{3}{*}{$<0.001^{* *}$} \\
\hline Range & & & & & 8-56 & & \\
\hline Median & & & & & 22 & & \\
\hline Post Hoc & \multicolumn{5}{|c|}{$\mathrm{P} 1=0.010^{\star}, \mathrm{P} 2:<0.001^{* \star}, \mathrm{P} 3:<0.001^{\star \star}$} & & \\
\hline \multicolumn{8}{|l|}{ CEA } \\
\hline Mean \pm SD & \multirow{3}{*}{\multicolumn{2}{|c|}{$\begin{array}{c}14.616 \pm 9.13 \\
2.10-4.00 \\
13.40\end{array}$}} & & \pm 6.21 & $8.56 \pm 4.05$ & \multirow[t]{3}{*}{15.87} & \multirow[t]{3}{*}{$0.046^{\star}$} \\
\hline Range & & & & 38.50 & $1.07-8.50$ & & \\
\hline Median & & & & & $10-45$ & & \\
\hline \multicolumn{8}{|l|}{ Pathology } \\
\hline Moclcate deff. & 2 & 9.09 & 0 & 0.00 & ------ & \multirow[t]{9}{*}{$\chi^{2}=16.523$} & \multirow[t]{9}{*}{$0.035^{\star}$} \\
\hline Mass $30 \mathrm{~cm}$ anal & 1 & 4.00 & 0 & 0.00 & & & \\
\hline T1N0 & 1 & 4.00 & 4 & 5.33 & & & \\
\hline T1N1 & 2 & 9.09 & 9 & 12.00 & & & \\
\hline T2NO & 2 & 9.09 & 4 & 5.33 & & & \\
\hline T2N1 & 1 & 4.00 & 11 & 11.67 & & & \\
\hline T3NO & 8 & 32.00 & 22 & 29.33 & & & \\
\hline T3N1 & 4 & 16.00 & 22 & 29.33 & & & \\
\hline T3N2 & 4 & 16.00 & 3 & 4.00 & & & \\
\hline
\end{tabular}

IGF1: Insulin-Like Growth Factor-1, CEA: Carcinoembryonic antigen, F-Test: ANOVA test.

${ }^{*}$ : statistically significant, NS: Non significant, ${ }^{* *}$ : Highly statistically significant, $\chi^{2}$ : chi-square test.

$\mathrm{P1}$ : comparison between Rectal group and Colon group

P2: comparison between Rectal group and Control group

P3: comparison between colon group and Control group

increased among overweight patients $(71.38 \pm 47.80)$, then obese patients $(67.57 \pm 19.84)$ with $p$ value 0.026 as shown in table 3.

There was no statistically correlation between insulin- like growth factor-1 with age, BMI, BP, Total cholesterol, Triglycerides, HDL, LDL, RBS and carcinoembryonic antigen among the studied groups, ( $p>0.05$ ) as shown in table 4 .

The best cutoff point of Insulin-Like Growth Factor-1 to differentiate between rectal and control groups was 85.70 with $90.60 \%$ sensitivity, 70.80 specificity, $25 \%$ PPV, 50\% NPV and $86.5 \%$ accuracy. Also, the best cutoff point of Insulin-Like Growth Factor-1 to differentiate between Colon and Control groups was 63.5 with $73 \%$ sensitivity, 45.54 specificity, 75\% PPV, 50\% NPV and $90.80 \%$ accuracy. The best cutoff point of Insulin-Like Growth Factor-1 to differentiate between Rectal and Colon groups was 152.1 with 81.60 tr\% sensitivity, $52 \%$ specificity, $29 \%$ PPV, $75 \%$ NPV and $81.10 \%$ accuracy as shown in table 5.

\section{DISCUSSION}

There are multiple common health consequences of an elevated body mass index (BMI), including risk for several metabolic disorders, some cancers and ultimately increased mortality (9). Cancer is the leading cause of death in developed countries and a second leading cause of death in developing countries (10-12). The number of cancer cases is expected to rise due to both world-wide population growth and an increasingly aged population. Timely screening of obese patients for CRC is thus recommended. Insulin is a major anabolic hormone which can stimulate both normal and malignant cell proliferation and its effect on cell proliferation is suggested to be with insulin-like growth factor 1 (IGF-1) stimulation (14-16). The study designed to determine the relationship between metabolic syndrome as a risk factor for colorectal cancer.

In this study, there was no statistically significant differences between the studied groups regarding gender, age/year, weight, height and BMI. Another study conducted by Bayerdorffer et al., (17) found that, mean age at baseline was 43.9 years in men and 44.1 years in women, and the mean follow-up was 12.8 years in men and 11.3 years in women. Ko et al., (18) found no statistically significant differences between the studied groups regarding height and weight. While, body mass index and waist were significantly lower among colorectal cancer patients than control groups. Also, our results were consistent with Harlid et al., (19) who found no significant difference between cases and controls regarding weight, height and BMI. In the study conducted by Milano et al., (20) there was highly statistically significant differences between Positive and negative colonoscopy patients regarding Waist circum- 
Table 3 - Relation between body mass index with lab investigation, IGF-1 and CEA among colon cancer patients

\begin{tabular}{|c|c|c|c|c|c|}
\hline & \multicolumn{3}{|c|}{ Colon cancer (N=75) } & \multirow[t]{2}{*}{ Test sig. } & \multirow[t]{2}{*}{$P$ value } \\
\hline & Normal & Overweight & Obese & & \\
\hline $\begin{array}{l}\text { Waist } \\
\text { Mean } \pm \text { SD } \\
\text { Range }\end{array}$ & $\begin{array}{c}81.81 \pm 5.66 \\
70.0-90.0\end{array}$ & $\begin{array}{c}86.45 \pm 3.87 \\
77.0-90.0\end{array}$ & $\begin{array}{c}88.71 \pm 10.29 \\
76.0-103.0\end{array}$ & 7.43 & $0.001^{*}$ \\
\hline $\begin{array}{l}\text { Systolic pressure } \\
\text { Mean } \pm \text { SD } \\
\text { Range }\end{array}$ & $\begin{array}{c}113.63 \pm 17.33 \\
100-180\end{array}$ & $\begin{array}{c}107.60 \pm 11.96 \\
90-140\end{array}$ & $\begin{array}{c}107.14 \pm 16.03 \\
90-140\end{array}$ & 0.205 & 0.814 NS \\
\hline $\begin{array}{l}\text { Diastolic pressure } \\
\text { Mean } \pm \text { SD } \\
\text { Range }\end{array}$ & $\begin{array}{c}70.09 \pm 12.50 \\
50-92\end{array}$ & $\begin{array}{c}66.21 \pm 11.76 \\
50-92\end{array}$ & $\begin{array}{c}69.42 \pm 17.65 \\
52-102\end{array}$ & 0.783 & $0.461 \mathrm{NS}$ \\
\hline $\begin{array}{l}\text { RBS }\left(\times 10^{\wedge} 3 / \mathrm{mm}^{3}\right) \\
\text { Mean } \pm \text { SD } \\
\text { Range }\end{array}$ & $\begin{array}{c}144.36 \pm 73.99 \\
80-320\end{array}$ & $\begin{array}{c}133.11 \pm 52.09 \\
88-350\end{array}$ & $\begin{array}{c}103.28 \pm 13.87 \\
80-126\end{array}$ & 3.357 & $0.026^{\star}$ \\
\hline $\begin{array}{l}\mathrm{LDL}(\mathrm{mg} / \mathrm{dl}) \\
\text { Mean } \pm \mathrm{SD} \\
\text { Range }\end{array}$ & $\begin{array}{c}119.68 \pm 68.29 \\
45-350\end{array}$ & $\begin{array}{c}129.02 \pm 55.08 \\
18-257\end{array}$ & $\begin{array}{c}151.85 \pm 58.57 \\
73-227\end{array}$ & 4.782 & $0.016^{*}$ \\
\hline $\begin{array}{l}\mathrm{HDL}(\mathrm{mg} / \mathrm{dl}) \\
\text { Mean } \pm \mathrm{SD} \\
\text { Range }\end{array}$ & $\begin{array}{c}41.04 \pm 7.70 \\
25-53\end{array}$ & $\begin{array}{c}44.10 \pm 13.07 \\
8-48\end{array}$ & $\begin{array}{c}40.00 \pm 6.78 \\
30-53\end{array}$ & 0.786 & $0.459 \mathrm{NS}$ \\
\hline $\begin{array}{l}\text { Cholesterol }(\mathrm{mg} / \mathrm{dl}) \\
\text { Mean } \pm \text { SD } \\
\text { Range }\end{array}$ & $\begin{array}{c}192.81 \pm 75.41 \\
112-480\end{array}$ & $\begin{array}{c}207.41 \pm 71.89 \\
45-431\end{array}$ & $\begin{array}{c}188.85 \pm 62.77 \\
109-282\end{array}$ & 0.420 & 0.658 NS \\
\hline $\begin{array}{l}\text { Triglycerides (mg/dl) } \\
\text { Mean } \pm \text { SD } \\
\text { Range }\end{array}$ & $\begin{array}{c}152.80 \pm 57.47 \\
73-310\end{array}$ & $\begin{array}{c}182.77 \pm 58.16 \\
93-315\end{array}$ & $\begin{array}{c}176.85 \pm 44.73 \\
112-232\end{array}$ & 3.279 & $0.040^{*}$ \\
\hline $\begin{array}{l}\text { IGF1 } \\
\text { Mean } \pm \text { SD } \\
\text { Range }\end{array}$ & $\begin{array}{c}54.82 \pm 12.95 \\
40-90\end{array}$ & $\begin{array}{c}71.38 \pm 47.80 \\
17.8-282\end{array}$ & $\begin{array}{c}67.57 \pm 19.84 \\
38-94\end{array}$ & 5.357 & $0.026^{*}$ \\
\hline $\begin{array}{l}\text { CEA } \\
\text { Mean } \pm \text { SD } \\
\text { Range }\end{array}$ & $\begin{array}{c}13.85 \pm 6.43 \\
5.4-28.3\end{array}$ & $\begin{array}{c}14.80 \pm 5.16 \\
5.6-32\end{array}$ & $\begin{array}{c}16.01 \pm 11.19 \\
5.8-38.5\end{array}$ & 0.359 & 0.699 NS \\
\hline
\end{tabular}

IGF1: Insulin-Like Growth Factor-1, CEA: Carcinoembryonic antigen, RBS: Random Blood Sugar, LDL: Low density lipids, HDL: High density lipids, f-test: ANOVA test. NS: Non-significant, ${ }^{*}$ : Statistically significant

ference and BMI $(p<0.001)$. Also, Stocks et al., (21) found that, the use of BMI as a measure of obesity is hampered by the finding that BMI is not a specific

Table 4 - Correlation between Insulin-Like Growth Factor-1 and various parameters in Colorectal cancer patients

\begin{tabular}{|c|c|c|c|c|}
\hline \multirow[t]{3}{*}{ Parameters correlated } & \multicolumn{4}{|c|}{ Insulin-Like Growth Factor-1 } \\
\hline & \multicolumn{2}{|c|}{ Rectal (N=25) } & \multicolumn{2}{|c|}{ Colon (N=75) } \\
\hline & $r$ & P-value & $r$ & P-value \\
\hline Age (years) & -0.015 & .899 & 0.071 & 0.735 \\
\hline $\mathrm{BMI}(\mathrm{kg} / \mathrm{m} 3)$ & -0.178 & 0.395 & 0.084 & 0.475 \\
\hline $\mathrm{BP}(\mathrm{mmHg})$ & -0.059 & 0.780 & 0.086 & 0.465 \\
\hline Total cholesterol (mg/dL) & 0.124 & 0.564 & -0.027 & 0.817 \\
\hline Triglycerides $(\mathrm{mg} / \mathrm{dL})$ & 0.037 & 0.862 & -0.014 & 0.904 \\
\hline $\mathrm{HDL}(\mathrm{mg} / \mathrm{dL})$ & 0.228 & 0.283 & 0.080 & 0.494 \\
\hline $\mathrm{LDL}(\mathrm{mg} / \mathrm{dL})$ & 0.089 & 0.680 & -0.011 & 0.923 \\
\hline $\mathrm{RBC}\left(\times 10^{\wedge} 3 / \mathrm{mm} 3\right)$ & 0.013 & 0.952 & -0.030 & 0.797 \\
\hline Carcinoembryonic antigen & 0.116 & 0.580 & -0.007 & 0.954 \\
\hline
\end{tabular}

BMI: Body mass index BP: Blood pressure HDL: High density lipoprotein LDL: Lowdensity lipoproteins RBC: Red blood cell, r: Spearman correlation coefficient, NS: Non significant at P-value $\square 0.05$, S: Significant at P-value $<0.05$, HS: Highly significant at P-value $<0.01$ measure of abdominal fat mass, which is linked to metabolic aberrations, such as insulin resistance (22).

This study showed no statistically significant

Table 5 - Diagnostic performance and test characteristics of Insulin-Like Growth Factor-1

\begin{tabular}{lccc}
\hline Test characteristics & \multicolumn{3}{c}{ Insulin-Like Growth Factor-1 } \\
\cline { 2 - 4 } & $\begin{array}{c}\text { Rectal vs. } \\
\text { Control }\end{array}$ & $\begin{array}{c}\text { Colon vs. } \\
\text { Control }\end{array}$ & $\begin{array}{c}\text { Rectal vs. } \\
\text { Control }\end{array}$ \\
\hline Best cutoff value & 85.70 & 63.5 & $<152.10$ \\
\hline AUC & 0.936 & 0.046 & 0.673 \\
\hdashline SE & 0.041 & 0.019 & 0.070 \\
\hline P-value & $<0.001^{* *}$ & $<0.001^{* *}$ & $0.010^{*}$ \\
\hline Sens \% & 90.60 & 73.00 & 81.60 \\
\hdashline Spec \% & 70.80 & 45.54 & 52.00 \\
\hline PPV \% & 25.00 & 75.00 & 29.00 \\
\hline NPV \% & 50.00 & 50.00 & 75.00 \\
\hline Accuracy \% & 86.5 & 90.80 & 81.10 \\
\hline
\end{tabular}

Sens.: sensitivity Spec.: specificity PPV: positive predictive value NPV: negative predictive value *: statistically significant, ${ }^{*}$ : Highly statistically significant. 


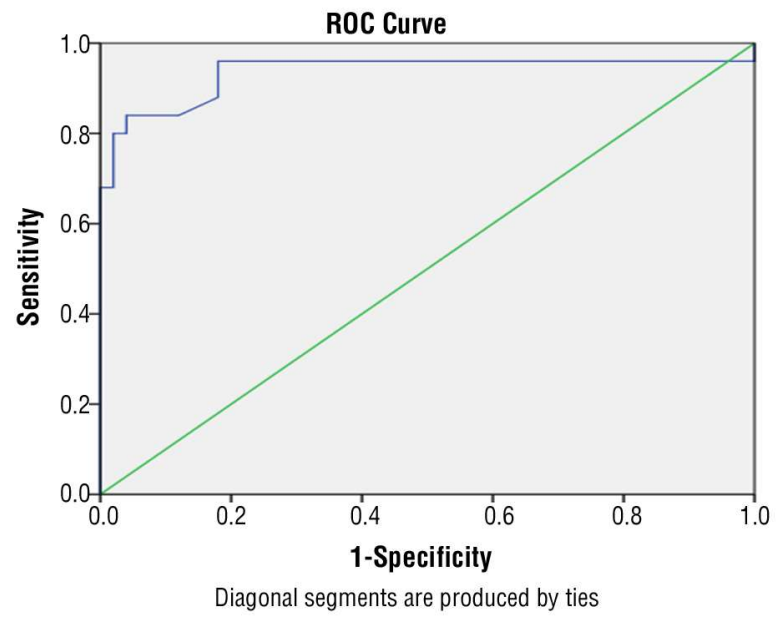

Figure 1 - Cutoff point of Insulin-Like Growth Factor-1 to differentiate between Rectal and Control groups

differences between colon and colorectal cancer patients regarding carcinoembryonic antigen. while insulin-like growth factor-1 were significantly higher among colorectal cancer patients than control groups. Our results consistent with Ishino et al., (23) who found insulin resistance is characteristic of metabolic syndrome, associated with high levels of fasting glucose, insulin and insulin-like growth factor (IGF-1) in the blood. It is considered that these conditions are linked to T2DM, and a higher risk of colon cancer (24-26). Also, Kukliński et al., (27) showed no significant differences in serum IGF I concentrations in patients compared to controls (28). In particular, for colon cancer, Giovannucci, (29) highlighted hyperinsulinemia as a main component among the metabolic risk factors because it mechanistically enhanced concentrations of insulin-like growth factor-1. Similar but statistically insignificant associations were noted in a small $(n=41)$ cohort of colorectal cancer patients from Greece (30). Their results did not confirm the widely adopted hypothesis that IGF I concentrations in colorectal cancer patients are higher compared to healthy individuals.

In the current study a significant difference found among the studied groups regarding Pathology $(p=0.035)$. Most of rectal cancer patients had T3NO (32\%) followed by T3N1 and T3N2 (16\% and 16\%). Also, most of colon cancer patients had T3NO and T3N1 (29.33\% and $29.33 \%$ ) followed by T2N1 (11.67\%). Kukliński et al., (27) found the stage of disease was classified based on histological criteria by WHO and TNM clinicopathological classification. No T1 subjects were found in the group studied. Stage T2, T3 and T4 tumors were revealed in 9 (7.2\%), 93 (74.4\%), and 23

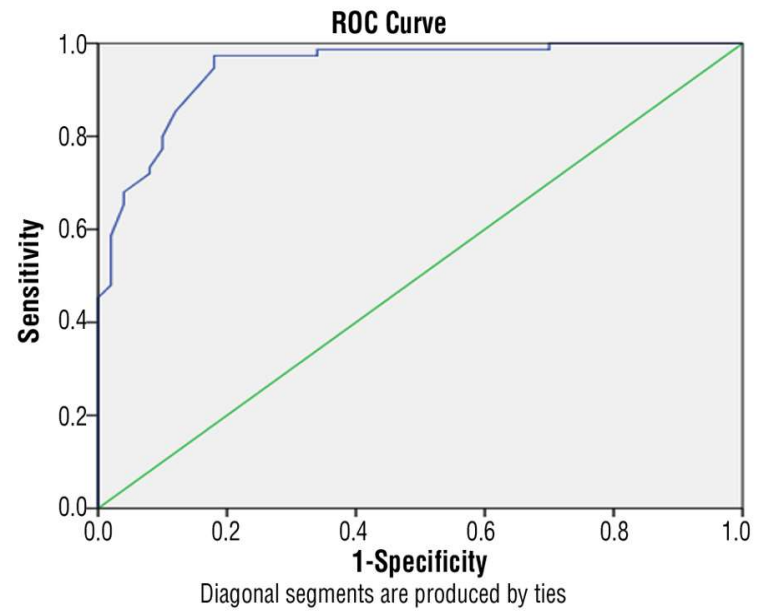

Figure 2 - Cutoff point of Insulin-Like Growth Factor-1 to differentiate between Colon and Control groups

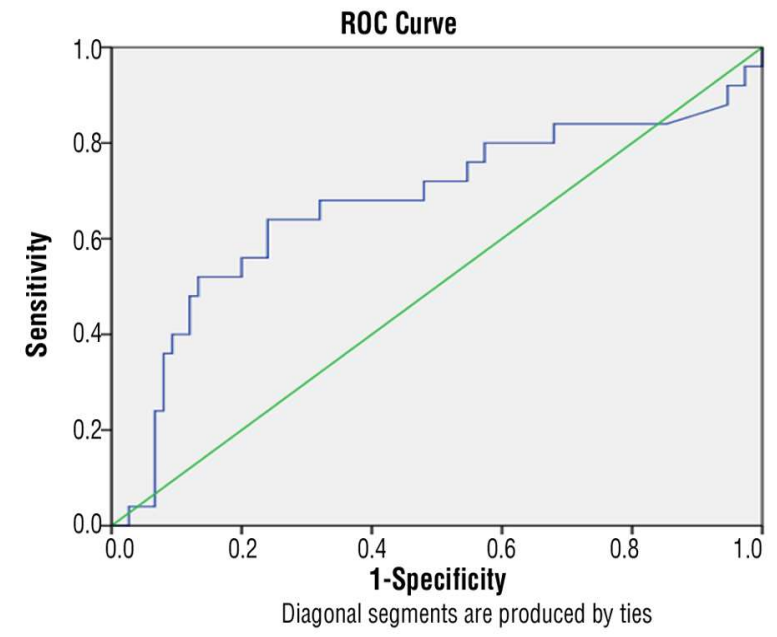

Figure 3 - Cutoff point of Insulin-Like Growth Factor-1 to differentiate between Rectal and Colon groups

(18.4\%) patients respectively. Lymph node involvement (group N0 according to TNM) was absent in 62 (49.6\%) patients. N1, N2 and N3 subjects comprised 31 (24.8\%), $28(22.4 \%)$, and $4(3.2 \%)$ cases respectively (31). In the study by Forootan et al., (32) Obesity is considered one of the major components of metabolic syndrome that is measured by different indicators including body mass index and abdominal obesity. $80 \%$ of women and $14 \%$ of men had abdominal obesity according to waist circumference that is in contrast with Pelucchi et al (33) and Pelucchi et al., (33). In studies that were able to separately examine the colon and rectum, relative risks were consistently higher for developing cancers of the colon. Similar relationships are seen for colon adenomas, with stronger associations between obesity and the incidence of larger (versus smaller) colon 
adenomas Giovannucci et al., (34).

This study showed that, there was no statistically significant relation between body mass index and diastolic pressure, systolic pressure, random blood sugar among control groups. While, waist was significantly higher among obese patients than overweight patients. Moreover, low- and high-density lipids, triglyceride as well as cholesterol levels were significantly increased among overweight patients than obese patients. There is converging evidence that markers of obesity have been associated with higher risk of colorectal cancer $(35,36)$. The findings of the study of Almurshed, (37) were not consistent with these results. The explanation may be that, although cases were newly diagnosed, they were in the advanced stages of carcinoma and this would reduce their weight, and therefore BMI. Though this is not in agreement with the literature, it is still suggested that colorectal cancer prevention programs should aim to reduce obesity both by encouraging regular exercise and consumption of diets rich in fibers, fruits, fresh vegetables and resistant starches.

In our results, no statistically correlation between insulin- like growth factor-1 with some different parameters among the studied groups. Kukliński et al., (27) found IGF I concentrations were significantly higher in patients below 60 years of age when compared to subjects over 60 years of age. Age-related changes in IGF I concentrations were described in detail by Hall et al. Levels of IGF I start to increase from the $6^{\text {th }}$ month of life while growth is continued up to puberty with a slight decrease thereafter. Then the concentration remains relatively constant to decrease again along with age Hall and Sara, (38). Clinical studies on Japanese males revealed inverse correlations between IGF I and IGF BP3 concentrations and patient age (39).

In this study, IGF I was significantly higher in males than in females. According to Clemmons et al., (40), both estrogens and androgens modulate somatomedin concentrations with similar impact. A small number of clinical research papers published on gender-related differences in IGF I levels do not allow for any further comparisons with our study findings. (41). Most of the published research deals with patient groups homogenous in terms of gender. Moreover, genderrelated differences in IGF I concentrations found preoperatively and postoperatively may have resulted from different body masses of the male and female patients (42). Increased BMI was associated with worsened outcomes for colon, cancer, but improved outcomes for renal cell carcinoma and endometrial cancer (43). There was no statistically significant difference regarding systolic and diastolic blood pressures, and this was in agreement with a study in Italy, which found a modest nonsignificant increase in the risk associated with hypertension. A similar modest nonsignificant association was found in another prospective study Gunter et al., (44).

In the present study, no significant difference was found with regarding total cholesterol, triglycerides, low-density lipoprotein, and HDL among the three studied groups. This was in agreement with Larsson et al., (43) who found in a prospective study that men and women in the top quartile of triglycerides have a nonsignificant $40 \%$ increased risk of colorectal cancer. Likewise, in another prospective study in the USA, an elevated triglyceride level was not a risk factor for colon cancer (45).

Regarding HDL, our finding was in agreement with a study conducted in Italy that found no association between the HDL-cholesterol level and the colorectal cancer risk Ma et al., (46). Also, in a cohort study, men and women in the top quartile of HDL-cholesterol had about a $40 \%$ nonsignificant reduction in the risk relative to those in the bottom quartile (47). The study was limited to only 1 hospital, this may introduce an element of selection bias for both cases and controls.

In our results, the best cutoff point of insulin-like growth factor-1 to differentiate between rectal and control groups was 85.70 with $90.60 \%$ sensitivity, 70.80 specificity, 25\% PPV, 50\% NPV and $86.5 \%$ accuracy. Also, the best cutoff point of Insulin-Like Growth Factor1 to differentiate between Colon and Control groups was 63.5 with $73 \%$ sensitivity, 45.54 specificity, $75 \%$ PPV, $50 \%$ NPV and $90.80 \%$ accuracy. The best cutoff point of Insulin-Like Growth Factor-1 to differentiate between Rectal and Colon groups was 152.1 with $81.60 \%$ sensitivity, $52 \%$ specificity, $29 \%$ PPV, $75 \%$ NPV and $81.10 \%$ accuracy. Yosry et al., (48) revealed that, there was an overall significant lower level of IGF-1 in CRC cases compared to normal controls. At a cutoff of $154 \mathrm{ng} / \mathrm{ml}$, IGF-1 can predict CRC with $87.5 \%$ sensitivity and 72.6 specificity (AUC $=0.79$ and $P$ value 0.006 with $95 \% \mathrm{Cl} ; 0.99-1$ ) but larger studies are recommended to prove this association.

\section{CONCLUSION}

Insulin-like growth factor-1 were significantly higher among colorectal cancer patients (rectal and clone) than control groups, Insulin like growth factor-1 was significantly increased among overweight and obese patients, The best cutoff point of insulin-like growth factor-1 to differentiate between rectal and control 
groups was 85.70 with sensitivity of $90.60 \%$ and specificity of $70.80 \%$ with accuracy $86.5 \%$, The best cutoff point of insulin-like growth factor-1 to differentiate between colon and control groups was 63.5 with $73 \%$ sensitivity, 45.54 specificity and $90.80 \%$ accuracy, The best cutoff point of Insulin-Like Growth Factor-1 to differentiate between rectal and colon groups was 152.1 with $81.60 \%$ sensitivity, $52 \%$ specificity, and $81.10 \%$ accuracy and We found that higher IGFBP1 levels were associated with the risk of colorectal cancer. Our findings indicate a potential role of IGFBP1 in the pathway for colorectal carcinogenesis.

\section{Conflict of Interest}

The authors declare no conflicts of interests.

\section{Ethical consideration}

All participants were volunteers. All of them signed a written informed consent with explaining the aim of study before the study initiation. Approval of the study protocol was obtained by Ethical Scientific Committee of Menoufia, Menoufia University Hospital and Kafr el sheikh University Hospital.

\section{REFERENCES}

1. Rahman S, Islam MT, Alam DS. Obesity and overweight in Bangladeshi children and adolescents: a scoping review. BMC public health. 2014;14(1):1-8.

2. Abdelaal M, le Roux CW, Docherty NG. Morbidity and mortality associated with obesity. Ann Transl Med. 2017;5(7):161.

3. Nagai H, Kim YH. Cancer prevention from the perspective of global cancer burden patterns. J Thorac Dis. 2017;9(3):448-451.

4. Jochem C, Leitzmann M. Obesity and colorectal cancer. Recent Results Cancer Res. 2016;208:17-41.

5. Bauml J. Oligometastatic Disease in Cancer: Broadening the Path to Cure? The Journal of Targeted Therapies in Cancer. 2018;7(2).

6. Simpson A, Petnga W, Macaulay VM, Weyer-Czernilofsky U, Bogenrieder T. Insulin-like growth factor (IGF) pathway targeting in cancer: role of the IGF axis and opportunities for future combination studies. Targeted Oncology. 2017;12(5):571-97.

7. Yuan J, Yin Z, Tao K, Wang G, Gao J. Function of insulin like growth factor 1 receptor in cancer resistance to chemotherapy. Oncology letters. 2018;15(1):41-7.

8. Adachi $\mathrm{Y}$, Nojima M, Mori M, Kubo T, Yamano HO, Lin $\mathrm{Y}$, et al. Circulating insulin-like growth factor binding protein-3 and risk of gastrointestinal malignant tumors. Journal of gastroenterology and hepatology. 2019;34(12):2104-11.

9. Berrington de Gonzalez A, Hartge P, Cerhan JR, Flint AJ, Hannan L, Maclnnis RJ, et al. Body-mass index and mortality among 1.46 million white adults. New England Journal of Medicine. 2010 363(23):2211-9.

10. Jemal A, Bray F, Center MM, Ferlay J, Ward E, Forman D. Global cancer statistics. CA: a cancer journal for clinicians. 2011;61(2): 69-90.

11. Siegel R, Naishadham D, Jemal A. Cancer statistics, 2012. CA: a cancer journal for clinicians. 2012;62(1):10-29.
12. Howlader NN, Noone AM, Krapcho ME, Miller D, Brest A, Yu M, et al. SEER cancer statistics review, 1975-2016. Bethesda, MD: National Cancer Institute. 2019:1423-37.

13. Ben $Q, A n W$, Jiang $Y$, Zhan $X, D u Y$, Cai $Q C$, et al. Body mass index increases risk for colorectal adenomas based on meta-analysis. Gastroenterology. 2012;142(4):762-72.

14. Williams RR, Sorlie PD, Feinleib M, McNamara PM, Kannel WB, Dawber TR. Cancer incidence by levels of cholesterol. Jama. 1981; 245(3):247-52.

15. Chung YW, Han DS, Park YK, Son BK, Paik CH, Lee HL, et al. Association of obesity, serum glucose and lipids with the risk of advanced colorectal adenoma and cancer: a case-control study in Korea. Digestive and Liver Disease. 2006;38(9):668-72.

16. Dessi S, Batetta B, Carrucciu A, Pulisci D, Laconi S, Fadda AM, et al. Variations of serum lipoproteins during cell proliferation induced by lead nitrate. Exp Mol Pathol. 1989;51(2):97-102.

17. Bayerdorffer E, Mannes GA, Richter WO, Ochsenkuhn T, Seeholzer G, Kopcke W, et al. Decreased high-density lipoprotein cholesterol and increased low-density cholesterol levels in patients with colorectal adenomas. Ann Intern Med. 1993;118(7):481-7.

18. Ko S, Yoon SJ, Kim D, Kim AR, Kim EJ, Seo HY. Metabolic risk profile and cancer in Korean men and women. J Prev Med Public Health. 2016;49(3):143-52.

19. Harlid S, Myte R, Van Guelpen B. The metabolic syndrome, inflammation, and colorectal cancer risk: an evaluation of large panels of plasma protein markers using repeated, prediagnostic samples. Mediators Inflamm. 2017;2017:4803156.

20. Milano A, Bianco MA, Buri L, Cipolletta L, Grossi E, Rotondano G, et al. Metabolic syndrome is a risk factor for colorectal adenoma and cancer: a study in a White population using the harmonized criteria. Therap Adv Gastroenterol. 2019:12:1-14.

21. Stocks T, Lukanova A, Bjørge T, Ulmer H, Manjer J, Almquist M, et al. Metabolic factors and the risk of colorectal cancer in 580,000 men and women in the metabolic syndrome and cancer project (MeCan). Cancer. 2011;117(11):2398-407.

22. Després JP, Lemieux I. Abdominal obesity and metabolic syndrome. Nature. 2006;444(7121):881-7.

23. Ishino $K$, Mutoh M, Totsuka $Y$, Nakagama H. Metabolic syndrome: a novel high-risk state for colorectal cancer. Cancer letters. 2013; 334(1):56-61.

24. Moghaddam AA, Woodward M, Huxley R. Obesity and risk of colorectal cancer: a meta-analysis of 31 studies with 70,000 events. Cancer Epidemiol Biomarkers Prev. 2007;16(12):2533-47.

25. Khandekar MJ, Cohen P, Spiegelman BM. Molecular mechanisms of cancer development in obesity. Nature Reviews Cancer. 2011; 11(12):886-95.

26. Ewton DZ, Kansra S, Lim S, Friedman E. Insulin-like growth factor-I has a biphasic effect on colon carcinoma cells through transient inactivation of forkhead1, initially mitogenic, then mediating growth arrest and differentiation. Int J Cancer. 2002;98(5):665-73.

27. Kuklinski A, Kamocki Z, Cepowicz D, Gryko M, Czyzewska J, Pawlak K, Kedra B. Relationships between insulin-like growth factor I and selected clinico-morphological parameters in colorectal cancer patients. Pol Przegl Chir. 2011;83(5):250-7.

28. Mendonca FM, de Sousa FR, Barbosa AL, Martins SC, Araújo RL, Soares R, Abreu C. Metabolic syndrome and risk of cancer: which link. Metabolism. 2015:64(2):182-9.

29. Giovannucci E. Metabolic syndrome, hyperinsulinemia, and colon cancer: a review. Am J Clin Nutr. 2007:86(3):s836-42.

30. Manousos 0, Souglakos J, Bosetti C, Tzonou A, Chatzidakis V, Trichopoulos D, et al. IGF-I and IGF-II in relation to colorectal cancer. Int J Cancer. 1999;83(1):15-7.

31. Shah MS, Fogelman DR, Raghav KP, Heymach JV, Tran HT, Jiang ZQ, et al. Joint prognostic effect of obesity and chronic systemic inflammation in patients with metastatic colorectal cancer. Cancer. 2015;121(17):2968-75.

32. Forootan M, Tabatabaeefar M, Yahyaei M, Maghsoodi N. Metabolic syndrome and colorectal cancer: a cross-sectional survey. Asian Pac J Cancer Prev. 2012;13(10):4999-5002.

33. Pelucchi C, Negri E, Talamini R, Levi F, Giacosa A, Crispo A, et al. 
Metabolic syndrome is associated with colorectal cancer in men. Eur $J$ Cancer. 2010;46(10):1866-72

34. Giovannucci E, Colditz GA, Stampfer MJ, Willett WC. Physical activity, obesity, and risk of colorectal adenoma in women (United States). Cancer Causes Control. 1996;7(2):253-63.

35. Frezza EE, Wachtel MS, Chiriva-Internati M. Influence of obesity on the risk of developing colon cancer. Gut. 2006;55(2):285-91.

36. Shimizu N, Nagata C, Shimizu H, Kametani M, Takeyama N, Ohnuma $\mathrm{T}$, et al. Height, weight, and alcohol consumption in relation to the risk of colorectal cancer in Japan: a prospective study. $\mathrm{Br} \mathrm{J}$ Cancer. 2003;88(7):1038-43

37. Almurshed KS. Colorectal cancer: case-control study of sociodemographic, lifestyle and anthropometric parameters in Riyadh. EMHJEast Mediterr Health J. 2009;15(4):817-26.

38. Hall K, Sara VR. Growth and somatomedins. Vitam Horm. 1983:40:175-233.

39. Teramukai S, Rohan T, Lee KY, Eguchi H, Oda T, Kono S. Insulin-like growth factor (IGF)-I, IGF-binding protein-3 and colorectal adenomas in Japanese men. Jpn J Cancer Res. 2002;93(11):1187-94.

40. Clemmons DR, Underwood LE, Ridgway EC, Kliman B, Kjellberg RN, van Wyk JJ. Estradiol treatment of acromegaly Reduction of immunoreactive somatomedin-C and improvement in metabolic status. Am J Med. 1980;69(4):571-5.

41. El Kafrawy NA, Glal AZ, Kandil MA, Dawood AA, Essa ES, Elgendy DS. A study of the relation between insulin resistance, insulin-like growth factor-1, and malignancy in type 2 diabetic patients. Menoufia Med J. 2015 Apr 1;28(2):494.

42. Friberg E, Orsini N, Mantzoros CS, Wolk A. Diabetes mellitus and risk of endometrial cancer: a meta-analysis. Diabetologia. 2007; 50(7):1365-74

43. Larsson SC, Mantzoros CS, Wolk A. Diabetes mellitus and risk of breast cancer: a meta-analysis. Int J Cancer. 2007;121(4):856-62.

44. Gunter MJ, Hoover DR, Yu H, Wassertheil-Smoller S, Rohan TE, Manson JE, et al. Insulin, insulin-like growth factor-I, and risk of breast cancer in postmenopausal women. J Natl Cancer Inst. 2009; 101(1):48-60.

45. Kaaks R, Toniolo P, Akhmedkhanov A, Lukanova A, Biessy C, Dechaud $H$, et al. Serum C-peptide, insulin-like growth factor (IGF)I, IGF-binding proteins, and colorectal cancer risk in women. J Natl Cancer Inst. 2000;92(19):1592-600.

46. Ma J, Giovannucci E, Pollak M, Leavitt A, Tao Y, Gaziano JM, et al. A prospective study of plasma C-peptide and colorectal cancer risk in men. J Natl Cancer Inst. 2004;96(7):546-53.

47. Jaggers JR, Sui X, Hooker SP, LaMonte MJ, Matthews CE, Hand GA, et al. Metabolic syndrome and risk of cancer mortality in men. Eur $\mathrm{J}$ Cancer. 2009;45(10):1831-8.

48. Yosry A, Omran D, Yousef M, Salah M, Omar H, Hamdy S, et al. SNPs in the insulin-like growth factor gene and obesity impact on colorectal cancer in Egyptians. Asian Pac J Cancer Prev. 2017; 18(11):2959-2964. 